\title{
SIGNIFIKANSI ELEMEN ARSITEKTUR BANGUNAN KOLONIAL BERGAYA ART DECO DI KOTA MALANG
}

\author{
Syamsun Ramli \\ Program Studi Magister Arsitektur Lingkungan Binaan, Jurusan Arsitektur, Fakultas Teknik, \\ Universitas Brawijaya, Malang \\ e-mail: syamsunramli@gmail.com \\ Herry Santosa \\ Dosen Jurusan Arsitektur, Fakultas Teknik, Universitas Brawijaya, Malang \\ e-mail: herrysantosa@ub.ac.id

\section{Antariksa} \\ Guru Besar Jurusan Arsitektur, Fakultas Teknik, Universitas Brawijaya, Malang \\ e-mail: antariksa@ub.ac.id
}

\begin{abstract}
ABSTRAK
Tampilan visual dan karakter bangunan dibentuk oleh elemen arsitekturnya. Bangunan bergaya Art Deco memiliki karakter tersendiri. Kota Malang berkembang pesat di era pemerintah Hindia Belanda pada tahun 1920 sampai 1938. Dalam rentang waktu tersebut gaya Art Deco sedang berkembang di Eropa. Tren ini berdampak terhadap bangunan di Kota Malang sehingga sebagian bangunan kolonial bergaya Art Deco. Bangunan-bangunan tersebut berada di kawasan yang memiliki nilai komersial yang tinggi. Hal ini dapat menyebabkan perubahan pada bangunan karena tuntutan komersial, baik keseluruhan bangunan maupun elemen arsitekturnya. Sehingga penelitian ini bertujuan untuk menilai signifikansi elemen arsitektur bangunan kolonial bergaya Art Deco di Kota Malang, sebagai upaya untuk mempertahankan karakter bangunan tersebut. Penelitian ini menggunakan pendekatan kuantitatif, dimana data didapatkan menggunakan kuesioner. Data yang diperoleh kemudian dianalisis menggunakan program SPSS. Hasil penelitian menunjukan bentuk bangunan, atap, kanopi, ornamen, material, dan warna berpengaruh signifikan terhadap karakter bangunan kolonial bergaya Art Deco di Kota Malang.
\end{abstract}

\section{Kata kunci : Signifikansi, Elemen Arsitektur, Art Deco, Bangunan Kolonial}

\begin{abstract}
Its architectural elements shape the visual appearance and character of a building. Art Deco-style buildings have their character. Malang City developed rapidly in the era of the Dutch East Indies government in 1920 to 1938. In that period, the Art Deco style was developing in Europe. This trend has an impact on buildings in the city of Malang so that some colonial buildings are Art Deco style. The buildings located in an area that has high commercial value. This can cause changes to the building due to commercial demands, both the entire building and architectural elements. So this study aims to assess the significance of the architectural elements
\end{abstract}


of the colonial-style Art Deco buildings in Malang, as an effort to maintain the character of the building. This research uses a quantitative approach, where data is obtained using a questionnaire. The data obtained were then analyzed using the SPSS program. The results showed that the shape of the building, roof, canopy, ornaments, materials, and colours significantly influence the character of the Art Deco-style colonial buildings in Malang..

\section{Keywords : Significance, Architectural Elements, Art Deco, Colonial Buildings}

\section{PENDAHULUAN}

Kota Malang merupakan kota yang pernah diduduki oleh Belanda. Surat kaputusan pembentukan Gemeente Kotapraja Malang menjadi bukti otentik berdirinya Kota Malang pada tanggal 1 April 1914. Perkembangan Kota Malang dipengaruhi UU Gula (Suikerwet) dan UU Agraria (Agrarischewet) (Handinoto. 1996). Sehingga Kota Malang berkembang menjadi kota perkebunan yang mengakibatkan peningkatan penduduk asing. Penduduk asing (Portugis, Jerman, Belanda, Perancis, Arab dan Tionghoa) mengalami pertumbuhan yang signifikan dari tahun 1920 sampai 1938 (Liempt 1939). Pertambahan penduduk asing tersebut membuat bangunan kolonial mengalami pertumbuhan. Bangunan kolonial tersebut ikut dipengaruhi oleh perkembangan gaya Art Deco di Eropa (Santoso 2017), dimana bangunan publik dan komersial bergaya Art Deco muncul pertama kali pada tahun 1920-an (Harris 2008), sedangkan dalam arsitektur gaya Art Deco banyak digunakan pada tahun 1930-an (Harris 2006). Sehingga beberapa bangunan kononial di Kota Malang bergaya Art Deco. Bangunanbangunan tersebut turut mempengaruhi karakter wajah bangunan di Kota Malang (Santoso 2017). Setiap Bangunan memiliki karakter yang dibentuk oleh elemen arsitektur (Antariksa 2017), dan bangunan kolonial bergaya Art Deco memiliki karakter tersendiri yang tercermin dari elemen arsitekturnya (Santoso 2017).

\section{TINJAUAN PUSTAKA}

Beberapa penelitian yang berlokasi di Kota Malang yaitu penelitian bangunan yang bernilai sejarah (Mulyadi 2014), penelitian karakteristik spasial dan visual koridor jalan provinsi berdasarkan preferensi publik (Santosa et al. 2018), dan penelitian yang menilai kulitas pencahayaan di siang dan malam pada bangunan bersejarah di koridor Kayutangan (Azis et al. 2019). Beberapa penelitian tentang elemen arsitektur yang pernah dilakukan diantaranya penilaian kualitas fasade bangunan modern pada 
Koridor Jalan Kayutangan (Fauziah et al. 2012). Penilaian elemen arsitektur bangunan bersejarah berdasarkan persepsi visual di Kota Kumbakonam India (Kiruthiga and Thirumaran 2017). Penelitian tentang bangunan kolonial bergaya Art Deco yaitu penelitian dengan menelusuri secara historis melalui visual bangunan art deco di Kota Malang (Santoso 2017), dimana penelitian tersebut menggunakan pendekatan kualitatif. Oleh karena itu, maka penelitian ini fokus untuk menilai signifikansi elemen arsitektur pada bangunan kolonial bergaya Art Deco di Kota Malang dengan pendekatan kuantitatif.

\section{METODE PENELITIAN}

Penelitian dilakukan di Kota Malang. Pendekatan yang dipilih adalah metode kuantitatif. Bangunan yang dijadikan studi kasus diperoleh dari penelitian sebelumnya tentang bangunan kolonial di Kota Malang. Kriteria yang digunakan untuk menentukan sampel bangunan adalah bangunan bergaya Art Deco, bangunan publik, mewakili fungsi tertentu (Mulyadi 2018), dan keaslian bangunan masih terjaga. Sehingga diperoleh tiga bangunan sebagai sampel yaitu:

- Toko Oen yang dibangun pada tahun 1930 (Mulyadi 2018) dengan fungsi komersial (perdagangan)

- Gereja Bromo yang dibangun pada tahun 1925, dengan fungsi keagamaan

- SMK Bina Cendika yang dibangun pada tahun 1936 (Handinoto. 1996) dengan fungsi pendidikan

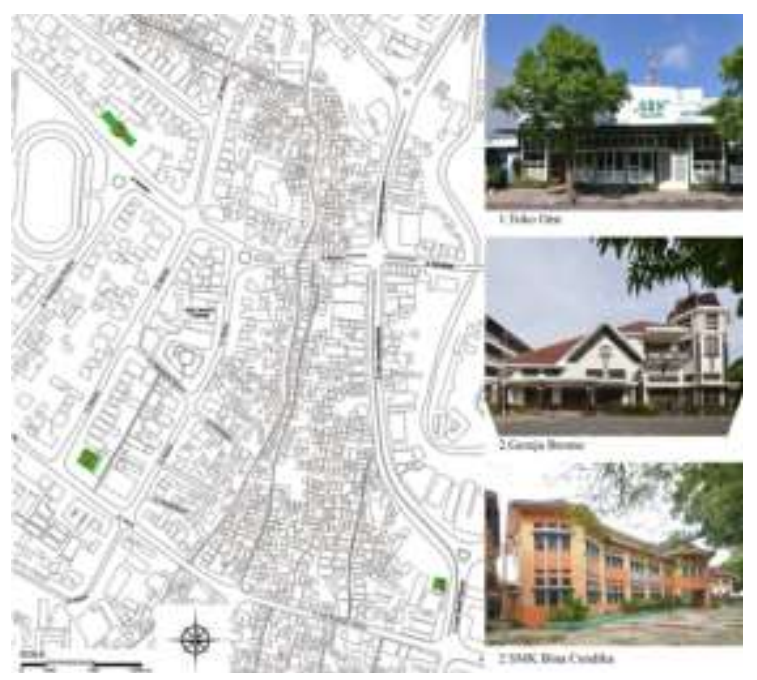

Gambar. 1

Lokasi Penelitian

Sumber: Peta Persil Kota Malang

Jurnal PAWON, Nomor 02 Volume IV, Bulan Juli-Desember Tahun 2020, ISSN 2597-7636 
Variabel penelitian berjumlah 13 yang diperoleh dari penelitian sebelumnya tentang elemen arsitektur yaitu: Fasade (Widyanti et al. 2009; Salura, 2013; Mulyadi, 2014; Mulyadi 2018; Jennath \& Nidhish, 2016). Bentuk bangunan (Mulyadi, 2018). Atap (Karisztia et al. 2008; Harani \& Motic, 2017; Santoso, 2017). Dinding (Karisztia et al. 2008; Harani \& Motic, 2017). Pintu (Widyanti et al. 2009; Harani \& Motic, 2017; Santoso, 2017). Jendela (Widyanti et. al. ,2009; Harani \& Motic, 2017; Santoso, 2017). Warna (Widyanti et al. 2009; Amir \& Binti Askari, 2009; Fauziah et al. 2012; Santosa et al. 2013; Jennath \& Nidhish, 2016). Ornamen (Widyanti et al., 2009; Amir \& Binti Askari, 2009; Fauziah et al. 2012; Santosa et al. 2013). Material (Amir \& Binti Askari, 2009; Fauziah et al. 2012; Santosa et al. 2013; Jennath \& Nidhish, 2016). Tekstur (Amir \& Binti Askari, 2009; Fauziah et al. 2012; Santosa et al. 2013). Kanopi (Santoso, 2017).. Variabel diukur menggunakan Semantic Differential Scale yang terdiri dari tujuh skala dan menggunakan kata-kata yang berlawanan. Penilaian negatif ada di sisi kiri dan penilaian positif ada di sisi kanan, sebagaimana diperlihatkan dalam Tabel 1.

Tabel 1.

Variabel Penelitian

\begin{tabular}{cclllllllll}
\hline \multirow{2}{*}{ No. } & \multirow{2}{*}{ Variabel } & \multicolumn{8}{c}{ Semantic Differential Scale } \\
\cline { 3 - 10 } & & \multicolumn{7}{c}{ Penilaian Signifikansi } \\
\hline 1 & Bentuk Bangunan & Sangat Tidak Signifikan & 1 & 2 & 3 & 4 & 5 & 6 & 7 & Sangat Signifikan \\
2 & Fasade & Sangat Tidak Signifikan & 1 & 2 & 3 & 4 & 5 & 6 & 7 & Sangat Signifikan \\
3 & Atap & Sangat Tidak Signifikan & 1 & 2 & 3 & 4 & 5 & 6 & 7 & Sangat Signifikan \\
4 & Kanopi & Sangat Tidak Signifikan & 1 & 2 & 3 & 4 & 5 & 6 & 7 & Sangat Signifikan \\
5 & Dinding & Sangat Tidak Signifikan & 1 & 2 & 3 & 4 & 5 & 6 & 7 & Sangat Signifikan \\
6 & Pintu & Sangat Tidak Signifikan & 1 & 2 & 3 & 4 & 5 & 6 & 7 & Sangat Signifikan \\
7 & Jendela & Sangat Tidak Signifikan & 1 & 2 & 3 & 4 & 5 & 6 & 7 & Sangat Signifikan \\
8 & Ornamen & Sangat Tidak Signifikan & 1 & 2 & 3 & 4 & 5 & 6 & 7 & Sangat Signifikan \\
9 & Material & Sangat Tidak Signifikan & 1 & 2 & 3 & 4 & 5 & 6 & 7 & Sangat Signifikan \\
10 & Tekstur & Sangat Tidak Signifikan & 1 & 2 & 3 & 4 & 5 & 6 & 7 & Sangat Signifikan \\
11 & Warna & Sangat Tidak Signifikan & 1 & 2 & 3 & 4 & 5 & 6 & 7 & Sangat Signifikan \\
12 & Seluruh Bangunan & Sangat Tidak Signifikan & 1 & 2 & 3 & 4 & 5 & 6 & 7 & Sangat Signifikan \\
\hline
\end{tabular}

Kuesioner digunakan untuk mengumpulkan data penilaian dari responden. Responden adalah masyarakat Kota Malang yang telah berusia di atas 18 tahun dan sehat secara rohani. Jumlah sampel minimal adalah: 12 variabel x $10=120$ sampel (Roscoe 1982). Sampel penelitian diambil menggunakan teknik random sampling. Masyarakat menilai variabel berdasarkan persepsi pribadi. Data yang diperoleh kemudian dianalisis menggunakan SPSS. Analisis SPSS yang digunakan adalah frequency, descriptive, dan multiple linear regression. Hasil descriptive analysis 
diklasifikasikan menggunakan tabel kontinum (Roscoe 1982) untuk menentukan tingkat signifikansi variabel. Tabel kontinum diperlihatkan oleh Tabel 2.

Tabel 2.

Tabel Kontinum

\begin{tabular}{cc}
\hline Skala & Tingkat Signifikansi \\
\hline $1,00-1.85$ & Sangat Tidak Signifikan \\
$1,86-2,71$ & Tidak Signifikan \\
$2,72-3,57$ & Agak Tidak Signifikan \\
$3,58-4,43$ & Biasa \\
$4,44-5,29$ & Agak Signifikan \\
$5,30-6,15$ & Signifikan \\
$6,16-7,00$ & Sangat Signifikan \\
\hline
\end{tabular}

\section{HASIL DAN PEMBAHASAN}

Responden yang telah berpartisipasi berjumlah 200 orang, terdiri dari 43 orang masyarakat umum $(21,5 \%), 17$ pegawai Disbubpar $(8,5 \%), 27$ orang pegawai Barenlibang (13,5\%), 29 pegawai DPUPR (14,5\%), 39 mahasiswa arsitektur (19,5\%), 32 dosen arsitektur (16), dan 13 anggota Ikatan Arsitek Indonesia (6,5\%). Mayoritas responden berdomisili di Kota Malang $(81,0 \%)$.

Hasil descriptive analysis memperlihatkan hampir 100\% elemen arsitektur signifikan mempengaruhi karakter bangunan, dimana elemen arsitektur adalah setiap komponen yang bersama-sama membentuk objek arsitektur (Archambault 2009) dan turut menentukan karakter arsitektur bangunan (Harris 2006).

\section{Toko Oen}

Toko Oen berada di Jalan Basuki Rahmat no. 5 Malang. Toko Oen merupakan salah satu bangunan yang selamat saat peristiwa bumi hangus di Malang pada Juli 1947 (TACB Kota Malang 2018). Toko Oen ditetapkan sebagai Cagar Budaya Kota Malang pada tahun 1980an, sehingga sampai saat ini keaslian bangunan tetap terjaga. Analisis signifikansi elemen arsitektur Toko Oen diperlihatkan oleh Tabel 3., Tabel 4., dan Tabel 5. 
Tabel 3.

Penilaian Signifikansi Elemen arsitektur Toko Oen

\begin{tabular}{|c|c|c|c|c|c|c|c|c|c|c|c|c|c|c|c|}
\hline \multirow{3}{*}{$\begin{array}{c}\text { Elemen } \\
\text { Arsitektur }\end{array}$} & \multicolumn{7}{|c|}{ Frequency } & \multirow{3}{*}{ Mean } & \multirow{3}{*}{ Tingkat Signifikansi } & \multirow{2}{*}{\multicolumn{6}{|c|}{ Grafik }} \\
\hline & 1 & 2 & 3 & 4 & 5 & 6 & 7 & & & & & & & & \\
\hline & STS & TS & TTS & $\mathrm{B}$ & AS & $\mathrm{S}$ & SS & & & 12 & 3 & 4 & 5 & 6 & 7 \\
\hline Bentuk Bangunan & 0 & 0 & 2 & 29 & 38 & 63 & 68 & $5,83^{* *}$ & Signifikan & & & & & $?$ & \\
\hline Fasade & 0 & 0 & 0 & 30 & 37 & 73 & 60 & 5,82 & Signifikan & & & & & & \\
\hline Atap & 0 & 4 & 4 & 42 & 42 & 67 & 41 & 5,44 & Signifikan & & & & & & \\
\hline Kanopi & 0 & 1 & 3 & 44 & 40 & 77 & 35 & 5,47 & Signifikan & & & & & & \\
\hline Dinding & 0 & 1 & 7 & 52 & 40 & 62 & 38 & 5,35 & Signifikan & & & & & & \\
\hline Pintu & 0 & 0 & 3 & 37 & 48 & 64 & 48 & 5,59 & Signifikan & & & & & & \\
\hline Jendela & 0 & 0 & 3 & 33 & 44 & 73 & 47 & 5,64 & Signifikan & & & & & & \\
\hline Ornamen & 0 & 3 & 5 & 35 & 43 & 73 & 41 & 5,51 & Signifikan & & & & & & \\
\hline Material & 0 & 0 & 7 & 50 & 48 & 58 & 37 & $5,34^{*}$ & Signifikan & & & & & & \\
\hline Tekstur & 0 & 1 & 5 & 51 & 41 & 60 & 42 & 5,40 & Signifikan & & & & & & \\
\hline Warna & 1 & 0 & 5 & 43 & 35 & 71 & 45 & 5,52 & Signifikan & & & & & & \\
\hline
\end{tabular}

Tabel 4.

Anova Signifikansi Elemen arsitektur Toko Oen

\begin{tabular}{|c|c|c|c|c|c|c|}
\hline \multicolumn{7}{|c|}{ ANOVA $^{\mathrm{a}}$} \\
\hline & Model & Sum of Squares & $\mathrm{df}$ & Mean Square & $\mathrm{F}$ & Sig. \\
\hline \multirow{3}{*}{1} & Regression & 124,424 & 11 & 11,311 & 23,740 &, $000^{b}$ \\
\hline & Residual & 89,576 & 188 & 0,476 & & \\
\hline & Total & 214,000 & 199 & & & \\
\hline
\end{tabular}

Predictors: (Constant), Warna, Ornamen, Atap, Jendela, Bentuk Bangunan, Kanopi, Material, Tekstur, Fasade, Dinding, Pintu

Dependent Variable: Karakter Toko Oen

Tabel 5.

Model Summary Signifikansi Elemen arsitektur Toko Oen

\begin{tabular}{ccccc}
\hline \multicolumn{5}{c}{ Model Summary $^{\mathbf{b}}$} \\
\hline Model & R & R Square & Adjusted R Square & Std. Error of the Estimate \\
\hline 1 &, $763^{\text {a }}$ & 0,581 & 0,557 & 0,690 \\
\hline
\end{tabular}

Predictors: (Constant), Warna, Ornamen, Atap, Jendela, Bentuk Bangunan, Kanopi, Material, Tekstur, Fasade, Dinding, Pintu

Dependent Variable: Karakter Toko Oen 


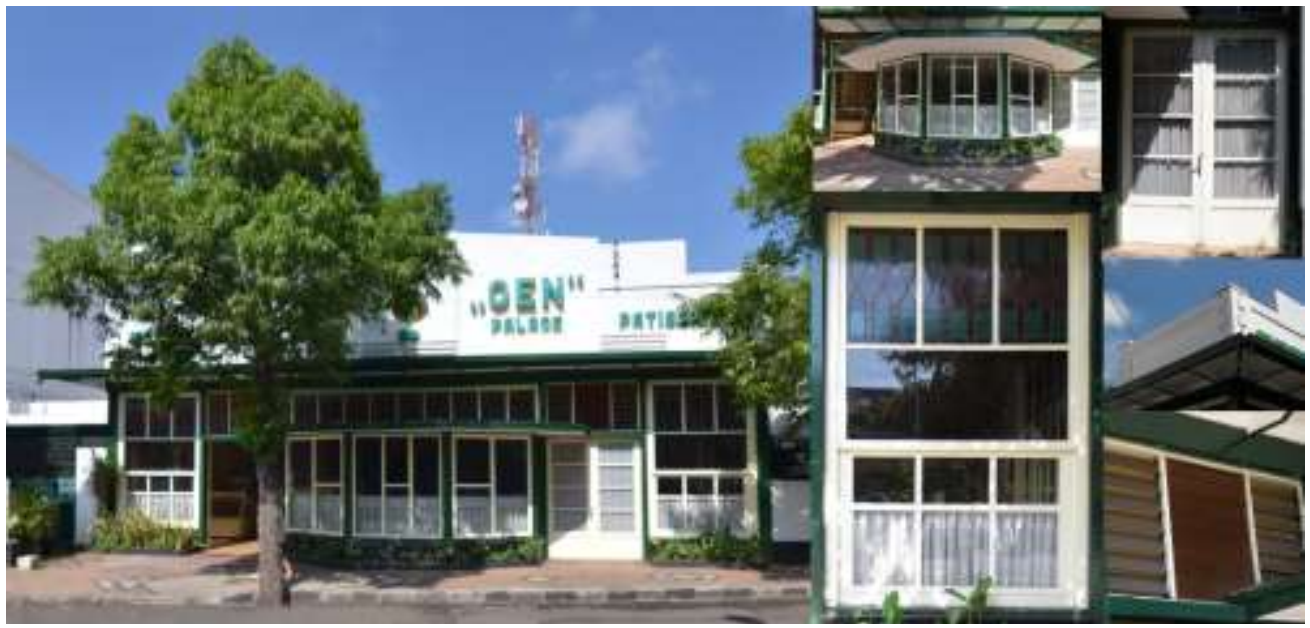

Gambar. 2

Toko Oen

Sumber: Ramli

Berdasarkan Tabel 3. terlihat bahwa $100 \%$ elemen arsitektur berpengaruh signifikan terhadap karakter Toko Oen. Bentuk bangunan menjadi elemen arsitektur yang memiliki signifikansi tertinggi dengan nilai rata-rata 5,83. Elemen arsitektur yang memiliki signifikansi terendah adalah material dengan nilai rata-rata 5,34. Tabel 4. memperlihatkan dua belas elemen arsitektur tersebut memiliki nilai rata-rata yang berbeda secara signifikan (Sig sebesar 0,000<0,05). Dari Tabel 5. dapat diketahui bahwa bentuk bangunan, fasade, atap, kanopi, dinding, pintu, jendela, ornamen, material, tekstur, dan warna memiliki korelasi yang kuat terhadap karakter Toko Oen $(R=0,763)$. Sehingga semua elemen arsitektur pada Toko Oen tersebut patut pertahankan. Elemen-elemen tersebut berkontribusi sebesar $58,1 \%$ terhadap karakter Toko Oen $(R$ Square $=0,581)$. Hal ini memperlihatkan terdapat indikasi ada aspek lain yang berpengaruh terhadap karakter Toko Oen.

\section{Gereja Bromo}

Gereja Bromo terletak di Jalan Bromo No. 2 Malang. Bangunan tersebut awalnya merupakan vila milik Han Tiauw An, seorang Kapitan Tionghoa. Kemudian Han Tiauw An menghibahkan rumah tersebut beserta tanahnya kepada Gereja Kristen Jawa Timur Malang pada tanggal 5 Januari 1961. Pihak gereja tetap menjaga keaslian bangunan hingga saat ini. 
Analisis signifikansi elemen arsitektur Gereja Bromo diperlihatkan oleh Tabel 6., Tabel 7., dan Tabel 8.

Tabel 6.

Penilaian Signifikansi Elemen arsitektur Gereja Bromo

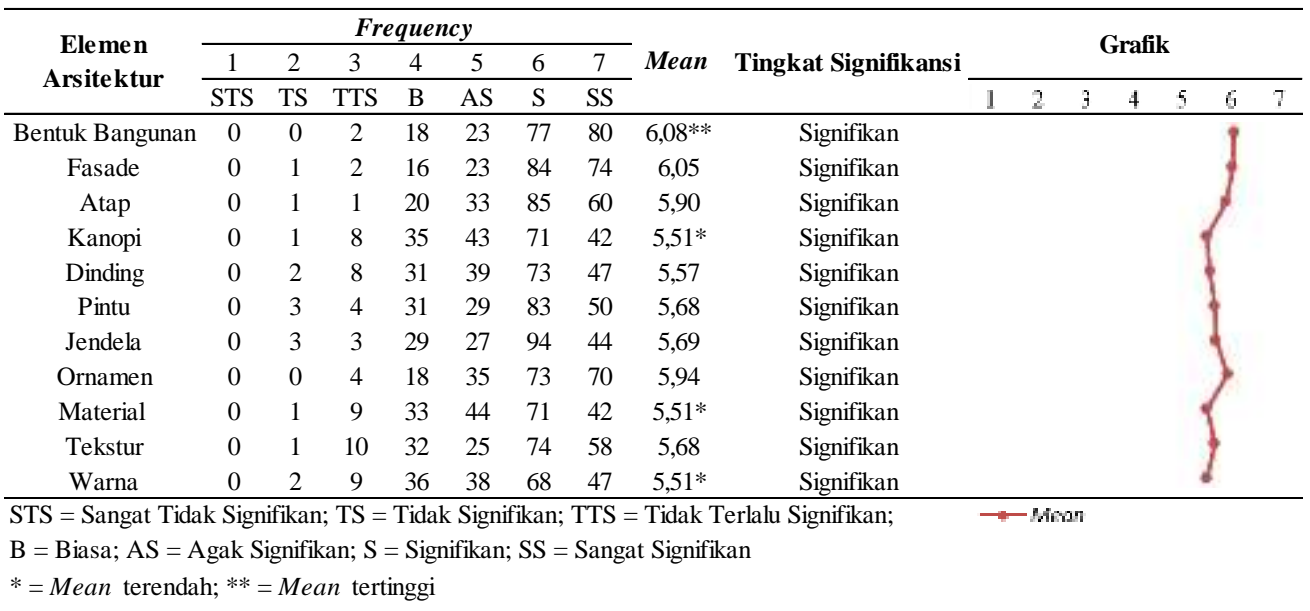

Tabel 7.

Anova Signifikansi Elemen arsitektur Gereja Bromo

\begin{tabular}{ccccccc}
\hline \multicolumn{8}{c}{ ANOVA $^{\mathbf{a}}$} \\
\hline \multicolumn{1}{c}{} & Model & Sum of Squares & df & Mean Square & F & Sig. \\
\hline \multirow{2}{*}{1} & Regression & 86,036 & 11 & 7,821 & 15,228 &, $000^{\mathrm{b}}$ \\
& Residual & 96,559 & 188 & 0,514 & & \\
& Total & 182,595 & 199 & & & \\
\hline
\end{tabular}

Predictors: (Constant), Warna, Ornamen, Atap, Jendela, Bentuk Bangunan, Kanopi, Material, Tekstur, Fasade, Dinding, Pintu

Dependent Variable: Karakter Gereja Bromo

Tabel 8.

Model Summary Signifikansi Elemen arsitektur Gereja Bromo

\begin{tabular}{ccccc}
\hline \multicolumn{4}{c}{ Model Summary $^{\mathbf{b}}$} \\
\hline Model & R & R Square & Adjusted R Square & Std. Error of the Estimate \\
\hline 1 &, $686^{\mathrm{a}}$ & 0,471 & 0,440 & 0,717 \\
\hline
\end{tabular}

Predictors: (Constant), Warna, Ornamen, Atap, Jendela, Bentuk

Bangunan, Kanopi, Material, Tekstur, Fasade, Dinding, Pintu

Dependent Variable: Karakter Gereja Bromo 


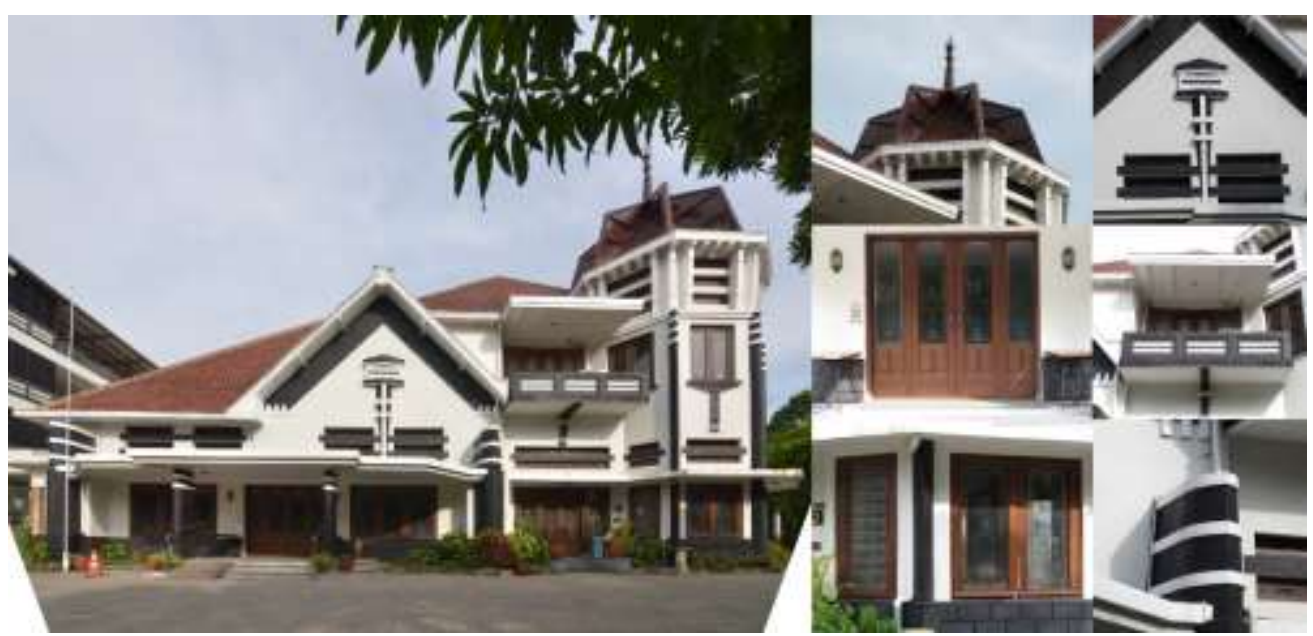

Gambar. 3

Gereja Bromo

Sumber: Ramli

Berdasarkan Tabel 6. tampak masyarakat menilai seluruh elemen arsitektur signifikan mempengaruhi karakter Gereja Bromo. Elemen arsitektur yang memiliki signifikansi tertinggi adalah bentuk bangunan dengan nilai rata-rata 6,08 . Kanopi, material, dan warna menjadi elemen arsitektur yang memiliki signifikansi terendah adalah dengan nilai rata-rata 5,51 . Tabel 7. memperlihatkan semua elemen arsitektur memiliki nilai ratarata yang berbeda secara signifikan (Sig sebesar 0,000 <0,05). Dari Tabel 8. (model summary) dapat diketahui bahwa bentuk bangunan, fasade, atap, kanopi, dinding, pintu, jendela, ornamen, material, tekstur, dan warna memiliki korelasi yang kuat terhadap karakter Gereja Bromo $(R=0,686)$. Sehingga penelitian merekomendasikan seluruh elemen tersebut dipertahankan, terutama bentuk bangunan. Elemen-elemen tersebut berkontribusi sebesar 47,1\% (R Square $=0,471$ ) terhadap karakter Gereja Bromo. Hal ini menunjukan adanya indikasi terdapat aspek lain yang berpengaruh terhadap karakter bangunan.

\section{SMK Bina Cendika}

SMK Bina Cendika berada di jalan Semeru no. 42 Malang. Gedung SMK Bina Cendika termasuk gedung yang selamat saat peristiwa bumi hangus Malang pada Juli 1947 (TACB Kota Malang 2018). Gedung SMK Bina Cendika masih terjaga keaslian sampai saat ini. Gedung SMK Bina Cendika merupakan tempat berdirinya Tentara Genie Pelajar (TGP) pada tahun 1947, dimana TGP merupakan cikal bakal kesatuan zeni TNI AD. 
Analisis signifikansi elemen arsitektur SMK Bina Cendika diperlihatkan oleh Tabel 9., Tabel 10., dan Tabel 11.

Tabel 9.

Penilaian Signifikansi Elemen arsitektur SMK Bina Cendika

\begin{tabular}{|c|c|c|c|c|c|c|c|c|c|c|c|c|c|c|}
\hline \multirow{3}{*}{$\begin{array}{c}\text { Elemen } \\
\text { Arsitektural }\end{array}$} & \multicolumn{7}{|c|}{ Frequency } & \multirow{3}{*}{ Mean } & \multirow{3}{*}{ Tingkat Signifikansi } & \multirow{2}{*}{\multicolumn{5}{|c|}{ Grafik }} \\
\hline & \multirow{2}{*}{$\begin{array}{c}1 \\
\text { STS }\end{array}$} & \multirow{2}{*}{$\begin{array}{c}2 \\
\text { TS }\end{array}$} & \multirow{2}{*}{$\begin{array}{c}3 \\
\text { TTS }\end{array}$} & \multirow{2}{*}{$\begin{array}{l}4 \\
\mathrm{~B} \\
\end{array}$} & \multirow{2}{*}{$\begin{array}{c}5 \\
\text { AS }\end{array}$} & \multirow{2}{*}{$\begin{array}{l}6 \\
S \\
\end{array}$} & \multirow{2}{*}{$\begin{array}{c}7 \\
\text { SS }\end{array}$} & & & & & & & \\
\hline & & & & & & & & & & 12 & 3 & 4 & 6 & 7 \\
\hline Bentuk Bangunan & 0 & 0 & 3 & 22 & 35 & 78 & 62 & $5,87 * *$ & Signifikan & & & & $?$ & \\
\hline Fasade & 1 & 0 & 4 & 28 & 33 & 85 & 49 & 5,72 & Signifikan & & & & & \\
\hline Atap & 1 & 2 & 4 & 31 & 46 & 78 & 38 & 5,53 & Signifikan & & & & & \\
\hline Kanopi & 0 & 1 & 5 & 35 & 49 & 79 & 31 & 5,47 & Signifikan & & & & & \\
\hline Dinding & 1 & 2 & 9 & 32 & 46 & 70 & 40 & 5,45 & Signifikan & & & & & \\
\hline Pintu & 1 & 1 & 6 & 42 & 50 & 63 & 37 & 5,38 & Signifikan & & & & & \\
\hline Jendela & 1 & 1 & 5 & 33 & 37 & 84 & 39 & 5,56 & Signifikan & & & & & \\
\hline Ornamen & 2 & 4 & 18 & 47 & 58 & 48 & 23 & $4,96^{*}$ & Agak Signifikan & & & & & \\
\hline Material & 1 & 2 & 6 & 48 & 54 & 62 & 27 & 5,23 & Signifikan & & & & & \\
\hline Tekstur & 3 & 2 & 4 & 44 & 50 & 73 & 24 & 5,26 & Signifikan & & & & & \\
\hline Warna & 1 & 5 & 10 & 43 & 41 & 72 & 28 & 5,23 & Signifikan & & & 6 & & \\
\hline STS = Sangat Tid & Sign & ikan & $\mathrm{TS}=$ & Tidal & 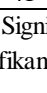 & - & 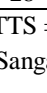 & Tidak T & rlalu Signifikan; & $-\infty$ & & & & \\
\hline
\end{tabular}

Tabel 10.

Annova Signifikansi Elemen arsitektur SMK Bina Cendika

\begin{tabular}{ccccccc}
\hline \multicolumn{8}{c}{ ANOVA $^{\mathbf{a}}$} & & & \\
\hline \multicolumn{1}{c}{} & Model & Sum of Squares & df & Mean Square & F & Sig. \\
\hline \multirow{2}{*}{1} & Regression & 158,326 & 11 & 14,393 & 31,212 &, $000^{\mathrm{b}}$ \\
& Residual & 86,694 & 188 & 0,461 & & \\
& Total & 245,020 & 199 & & & \\
\hline
\end{tabular}

Predictors: (Constant), Warna, Ornamen, Atap, Jendela, Bentuk Bangunan, Kanopi, Material, Tekstur, Fasade, Dinding, Pintu

Dependent Variable: Karakter SMK Bina Cendika

Tabel 11.

Model Summary Signifikansi Elemen arsitektur SMK Bina Cendika

\begin{tabular}{ccccc}
\hline \multicolumn{4}{c}{ Model Summary $^{\mathbf{b}}$} \\
\hline Model & $\mathrm{R}$ & R Square & Adjusted R Square & Std. Error of the Estimate \\
\hline 1 &, $804^{\mathrm{a}}$ & 0,646 & 0,625 & 0,679 \\
\hline
\end{tabular}

Predictors: (Constant), Warna, Ornamen, Atap, Jendela, Bentuk

Bangunan, Kanopi, Material, Tekstur, Fasade, Dinding, Pintu

De pendent Variable: Karakter SMK Bina Cendika 


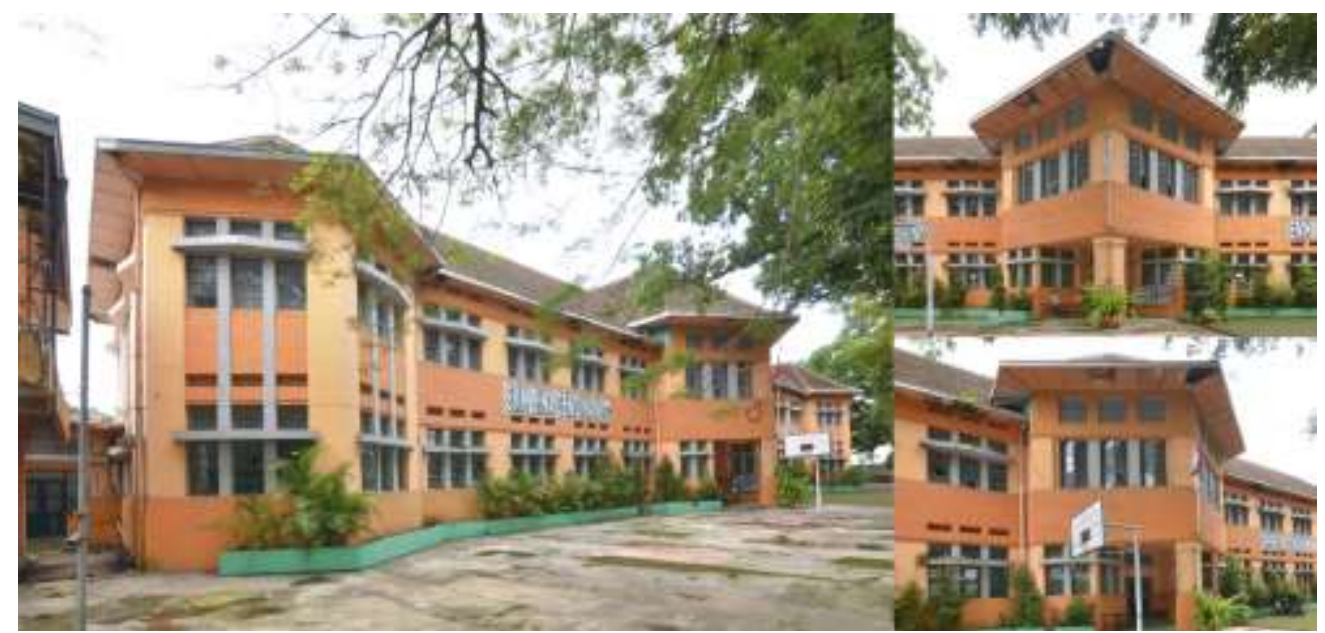

Gambar. 4

SMK Bina Cendika

Sumber: Ramli

Berdasarkan Tabel 9. dapat diketahui bahwa masyarakat menilai hampir seluruh elemen arsitektur berpengaruh signifikan terhadap gedung SMK Bina Cendika, kecuali ornamen yang dinilai agak signifikan mempengaruhi karakter bangunan. Bentuk bangunan memiliki nilai signifikansi tertinggi dengan nilai rata-rata 5,87. Tabel 10. menunjukan semua elemen arsitektur memiliki nilai rata-rata yang berbeda secara signifikan (Sig sebesar $0,000<0,05$ ). Tabel 10 . (model summary) memperlihatkan bentuk bangunan, fasade, atap, kanopi, dinding, pintu, jendela, ornamen, material, tekstur, dan warna memiliki korelasi yang sangat kuat terhadap karakter bangunan SMK Bina Cendika $(R=0,804)$. Elemenelemen tersebut berkontribusi sebesar $64,6 \%$ terhadap karakter SMK Bina Cendika ( $R$ Square $=0,646)$. Hal ini menunjukan indikasi ada aspek lain yang mempengaruhi karakter bangunan.

\section{Bangunan Kolonial Bergaya Art Deco}

Masyarakat menilai bentuk bangunan merupakan elemen arsitektur yang paling berpengaruh signifikan terhadap karakter bangunan. Berdasarkan Tabel 12. dapat diketahui bahwa elemen arsitektur (predictors) memiliki korelasi yang kuat terhadap karakter bangunan kolonial bergaya Art Deco di Kota Malang $(R=0,726)$. Elemen-elemen tersebut berkontribusi sebesar $52,8 \%$ terhadap karakter bangunan ( $R$ Square $=0,528$ ). 
Tabel 12.

Model Summary Signifikansi Elemen arsitektur Bangunan Kolonial Bergaya Art Deco

\begin{tabular}{ccccc}
\hline \multicolumn{5}{c}{ Model Summary $^{\mathbf{b}}$} \\
\hline Model & R & R Square & Adjusted R Square & Std. Error of the Estimate \\
\hline 1 &, $726^{\mathrm{a}}$ & 0,528 & 0,519 & 0,731 \\
\hline
\end{tabular}

Predictors: (Constant), Warna, Ornamen, Atap, Jendela, Bentuk

Bangunan, Kanopi, Material, Tekstur, Fasade, Dinding, Pintu

Dependent Variable: Karakter Bangunan

Tabel 13.

Multiple Linear Regression Signifikansi Elemen arsitektur Bangunan Kolonial Bergaya Art Deco

\begin{tabular}{cccccc}
\hline \multicolumn{7}{c}{ Coefficients $^{\mathbf{a}}$} \\
\cline { 1 - 4 } & $\begin{array}{c}\text { Unstandardized } \\
\text { Coefficients }\end{array}$ & $\begin{array}{l}\text { Standardized } \\
\text { Coefficients }\end{array}$ & & \\
\cline { 2 - 4 } & B & Std. Error & Beta & & Sig. \\
\cline { 2 - 4 } (Constant) & 1,160 & 0,192 & & 6,030 & 0,000 \\
Bentuk Bangunan & $\mathbf{0 , 2 7 1}$ & 0,048 & 0,266 & 5,645 & $\mathbf{0 , 0 0 0}$ \\
Fasade & 0,066 & 0,054 & 0,066 & 1,221 & 0,223 \\
Atap & 0,110 & 0,048 & 0,118 & 2,281 & $\mathbf{0 , 0 2 3}$ \\
Kanopi & 0,100 & 0,046 & 0,104 & 2,177 & $\mathbf{0 , 0 3 0}$ \\
Dinding & 0,026 & 0,052 & 0,029 & 0,491 & 0,624 \\
Pintu & $-0,007$ & 0,065 & $-0,007$ & $-0,101$ & 0,920 \\
Jendela & 0,054 & 0,056 & 0,057 & 0,968 & 0,334 \\
Ornamen & 0,164 & 0,038 & 0,191 & 4,313 & $\mathbf{0 , 0 0 0}$ \\
Material & $-0,136$ & 0,053 & $-0,149$ & $-2,591$ & $\mathbf{0 , 0 1 0}$ \\
Tekstur & 0,053 & 0,050 & 0,061 & 1,066 & 0,287 \\
Warna & 0,120 & 0,038 & 0,139 & 3,166 & $\mathbf{0 , 0 0 2}$ \\
\hline
\end{tabular}

Dependent Variable: Karakter Bangunan

Tabel 13. Menunjukan bentuk bangunan, atap, kanopi, ornamen, material, dan warna berpengaruh signifikan terhadap karakter bangunan kolonial bergaya Art Deco di Kota Malang. Bangunan bergaya Art Deco menekankan penggunaan bentuk-bentuk geometris (Harris 2006), oleh 
karena itu bentuk bangunan berpengaruh signifikan terhadap karakter bangunan. Bentuk geometris ini dapat dilihat di seluruh sampel bangunan. Atap menjadi elemen arsitektur yang berpengaruh signifikan terhadap karakter bangunan karena atap Art Deco memiliki karakter tersendiri, dimana atap bisa berbentuk atap datar dengan tembok pembatas atau atap berbentuk menara (Dewidar 2018). Atap datar dengan tembok pembatas dapat dilihat pada bangunan Toko Oen dan atap berbentuk menara ada pada Gereja Bromo. Kanopi menjadi elemen arsitektur yang berpengaruh signifikan pada bangunan kolonial bergaya Art Deco di Kota Malang. Hal ini dipengaruhi oleh iklim Kota Malang yang memiliki curah hujan tinggi (Dewidar 2018), berbeda dengan bangunan Art Deco di Eropa yang tidak menggunakan kanopi. Signifikansi kanopi ini selaras dengan hasil penelitian sebelumnya yang menyatakan kanopi sebagai elemen yang ada pada bangunan kolonial bergaya Art Deco di Kota Malang (Santoso 2017). Gaya Art Deco mengedepankan ornamen (Mulyadi 2018) yang berbentuk geometris (Dewidar 2018). Ornamen tersebut dapat dilihat pada bangunan Toko Oen dan Gereja Bromo, tetapi tidak terlihat pada bangunan SMK Bina Cendika. Bangunan bergaya Art Deco juga menekankan penggunaan material dengan karakter aslinya (Allen and Rand 2016), oleh karena itu material menjadi elemen penting pada bangunan bergaya Art Deco (Dewidar 2018). Dalam penelitian ini ditemukan perbedaan tentang signifikansi fasade, dimana penelitian sebelumnya berpendapat bahwa fasade sangat penting pada bangunan bergaya Art Deco (Mulyadi 2018), tetapi pada penelitian ini ada indikasi fasade tidak berpengaruh signifikan terhadap karakter bangunan (lihat Tabel 13.). Karakter bangunan bergaya Art Deco juga terlihat dalam penggunaan warna-warna berani seperti kuning, hijau, merah delima, dan pirus (Marta 2009). Warna hijau pada Toko Oen dan warna oranye pada SMK Bina Cendika mencerminkan karakter bangunan bergaya Art Deco.

\section{KESIMPULAN}

Elemen arsitektur memiliki korelasi yang kuat terhadap karakter bangunan kolonial bergaya Art Deco di Kota Malang. Elemen arsitektur yang berpengaruh signifikan terhadap karakter bangunan adalah bentuk bangunan, atap, kanopi, ornamen, material, dan warna. Elemen arsitektur yang paling berpengaruh signifikan adalah bentuk bangunan. Sehingga elemen arsitektur pada bangunan kolonial bergaya Art Deco di Kota Malang perlu dipertahankan agar karakter bangunan tetap terjaga. Di dalam penelitian ini ditemukan indikasi ada aspek lain yang ikut mempengaruhi karakter bangunan, sehingga penelitian selanjutnya diharapkan menemukan aspek tersebut. 


\section{DAFTAR PUSTAKA}

Allen, E, and P Rand. 2016. Architectural Detailing: Function, Constructibility, Aesthetics: Third Edition Architectural Detailing: Function, Constructibility, Aesthetics: Third Edition.

Amir, Hossein, and Kamariah Binti Askari. 2009. 5 Journal of Design and the Built Environment Influence of Building Façade Visual Elements on Its Historical Image Influence of Building Façade Visual Elements on Its Historical Image: Case of Kuala Lumpur City, Malaysia.

Antariksa. 2017. Teori \& Metode Pelestarian Arsitektur Dan Lingkungan Binaan. 1st ed. Yogyakarta: Cahaya Atma Pustaka.

Archambault, Ariane. 2009. The Visual Dictionary of Art \& Architecture: Art \& Architecture. Montreal: QA International.

Azis, Baskoro, Herry Santosa, and Jenny Ernawati. 2019. "Assessing Public Perception For Illumination of Building In Kayutangan Street, Malang, Indonesia." DIMENSI (Journal of Architecture and Built Environment) 46: 1122.

Dewidar, Khaled. 2018. Art Deco Architectural Style.

Dwi Karisztia, Arthantya, Galih Widjil Pangarsa, and Antariksa Sudikno. 2008. 1 arsitektur e-Journal Tipologi Façade Rumah Tinggal Kolonial Belanda Di Kayutangan-Malang.

Fauziah, Nur, Antariksa Sudikno, and Jenny Ernawati. 2012. 10 Jurnal RUAS Kualitas Visual Fasade Bangunan Modern Pasca Kolonial Di Jalan Kayutangan Malang.

Gavin Ambrose, Paul Harris, Sally Stone. 2008. The Visual Dictionary of Architecture. Lausanne: AVA Publishing SA.

Handinoto., Paulus $\mathrm{H}$ Soehargo, and Universitas Kristen PETRA. 1996. "Perkembangan Kota \& Arsitektur Kolonial Belanda Di Malang." Arsitektur kolonial Belanda di Malang: iv, 230 p.

Harris, Cyril M. 2006. Dictionary of Architecture \& Construction. Fourth. New York Chicago San Francisco Lisbon London Madrid Mexico City Milan New Delhi San Juan Seoul Singapore Sydney Toronto: The McGraw-Hill Companies, Inc. 
Jennath, K Aysha, and P J Nidhish. 2016. "Aesthetic Judgement and Visual Impact of Architectural Forms: A Study of Library Buildings." Procedia Technology 24: 1808-18.

http://www.sciencedirect.com/science/article/pii/S2212017316303176.

Kiruthiga, K., and K. Thirumaran. 2017. "Visual Perception on the Architectural Elements of the Built Heritage of a Historic Temple Town: A Case Study of Kumbakonam, India." Frontiers of Architectural Research 6(1): 96-107.

Lalu Mulyadi, Gaguk Sukowiyono. 2014. "Kajian Bangunan Bersejarah Di Kota Malang Sebagai Pusaka Kota (Urban Heritage) Pendekatan Persepsi Masyarakat." In Temu IImiah IPLBI 2014,.

Liempt. 1939. Stadsgemeente Malang 1914-1939. Soerabaia: Gedrukt Bij N. V. G. Kolff \& Co. TE Soerabaia.

Marta. 2009. "Art Deco Architecture." Art Deco Style. http://artdecostyle.ca/art-decostyle-blog/art-deco-architecture (November 5, 2019).

Mulyadi, Lalu. 2018. Model Pengelolaan Bangunan Bernilai Sejarah Di Kota Malang Berbasis Konservasi Arsitektur. Malang: Dream Litera Buana. http://arsitekturlalu.com/model-pengelolaan-bangunan-bernilai-sejarah-di-kota-malangberbasis-konservasi-arsitektur/.

Rochma Harani, Arnis, and Ken Motic. 2017. 5 Jurnal Pengembangan Kota Pengaruh Fasade Bangunan Terhadap Karakter Visual Kawasan (Studi Kasus: Pecinan Semarang, Malaysia Dan Singapura).

Roscoe. 1982. Research Methods For Business. New York: Mc Graw Hill.

Salura, Purnama. 2013. Journal of Basic and Applied Scientific Research Conservation of Dutch Colonial Architecture Heritage on Rectorate Building of Education University of Indonesia Bandung.

Santosa, Herry, J Ernawati, and Lisa Wulandari. 2018. "Visual Quality Evaluation of Urban Commercial Streetscape for the Development of Landscape Visual Planning System in Provincial Street Corridors in Malang, Indonesia." IOP Conference Series: Earth and Environmental Science 126: 12202.

Santosa, Herry, Shinji Ikaruga, and Takeshi KOBAYASHI. 2013. "Visual Evaluation of Urban Commercial Streetscape Through Building Owners Judgment." Journal of Architecture and Planning (Transactions of AlJ) 78: 1995-2005. 
Santoso, Imam. 2017. "Penelusuran Historis Melalui Visual Bangunan Art Deco. Sebuah Upaya Buffer Kualitas Wajah Kota Ke Era Komersialisasai Di Malang." MINTAKAT Jurnal Arsitektur, Volume I Nomor I, Maret 2017.

TACB Kota Malang. 2018. Bangunan Cagar Budaya Di Kota Malang. Cetakan I. Malang: Dinas Kebudayaan dan Pariwisata Kota Malang.

Tri Widyanti, Artika, Antariksa, and Ema Yunita Titisari. 2009. "Pelestarian Stasiun Kereta Api Kota Baru Malang." arsitektur e-journal. 